\title{
COMPARISON OF POPULATION AND FEEDING ECOLOGY OF TWO ENDANGERED VARANID LIZARDS OF BANGLADESH
}

\author{
M. Firoj Jaman ${ }^{1}$, M. Anisa Begum* and H. Mahmud** \\ Department of Zoology, University of Dhaka, Dhaka 1000, Bangladesh \\ Email:mfjaman@yahoo.com/jaman@pri.kyoto-u.ac.jp \\ *Department of Sociology, University of Dhaka, Bangladesh \\ **Global Studies Program, Sophia University, Tokyo, Japan. \\ ${ }^{1}$ Mailing correspondence \\ Department of Ecology and Social Behavior \\ Primate Research Institute, Kyoto University, 41-2 Kanrin, Inuyama, Aichi, Japan
}

\begin{abstract}
A comparative study on population and feeding ecology of Bengal monitor and yellow monitor had been done between March 2003 and August 2004 in four distinct study areas of Bangladesh. Plots population of gray land monitor $\left(14.11 \pm 5.66\right.$ individual $\left./ \mathrm{km}^{2}\right)$ showed significantly higher than that in transect lines $\left(8.77 \pm 2.96\right.$ individual $\left./ \mathrm{km}^{2}\right)$. Population density both in plots $\left(21.42 / \mathrm{km}^{2}\right)$ and transect lines $\left(11.98 / \mathrm{km}^{2}\right)$ was the highest in Kapasia, Gazipur district. In case of yellow monitors, plots population was also significantly higher than that of transect population and the highest population was counted from the Karnai study sites both in plots and transects censuses. The overall population of Bengal monitors was significantly higher than that of yellow monitors. Among the total consumed food items, animal food was the highest $(86.25 \%)$ in the gut of Bengal monitors. Of the total animal food, arthropods $(39.89 \%)$ was the highest scored followed by annelids $(28.84 \%)$. Among the arthropods, decapodans was (16.17\%) preferred foods items followed by coleopterans $(9.7 \%)$. On the other hand, yellowed monitors also preferred animal foods $(82.06 \%)$ in which the most preferred diet was vertebrate animals $(54.82 \%)$, particularly fishes $(27.24 \%)$. Finding of this study was that grey land monitor preferred invertebrate foods whereas yellow monitor preferred vertebrate foods. Significant difference in their food habits might be the consequences of different ecological niche between the species that actually needed to be further studied.The ecological differences between the species might contribute for the solution of conservation problem of these endangered lizard species.
\end{abstract}

Key words: Population, feeding ecology, endangered varanids, conservation.

\section{INTRODUCTION}

Four species of monitor lizards, the Bengal Monitor, Varanus bengalensis; Yellow Monitor, $V$. flavescens; Ring Water Monitor, V. salvator; and Black Monitor, $V$. nebulosa are found in Bangladesh territory (Akhond et al. 1982). Bengal monitor and yellow water monitor are widely distributed in Bangladesh while Ring water monitor is found only on the coastal region of ECOPRINT VOL 14, 2007
Bangladesh including Sundarban, St. Martins and Maheskhali Islands (Sarker and Sarker 1988). Lokman and Sarker (1996) studied the population status of first three species from Hatiya Island, Bangladesh. Black monitor is occasionally found and its distribution is not well understood. Very few studies have been conducted on the population and feeding ecology of monitor lizards in Bangladesh though some studies have already been 
done elsewhere (Cowles 1930, Igolkina 1975, Whitaker and Hikida 1981, Auffenberg 1981, Akond et al. 1982, Sarker and Sarker 1985, Auffenberg et al. 1989, Sarker 1991, Murphy 1992, Hossain et al. 1995, Hossain and Sarker 1996, Ahsan 1996). Some information on ecology and distribution of monitors are available in the literature (Deraniyagala 1939, 1953, Hvass 1964, Jeoh and Ramaswanj 1976, Rose 1967, Sarker and Sarker 1988, Auffenberg 1988, Anon 2000, Daniel 1992).

In spite of their importance in maintaining ecobalance and also their positive contribution to national economy, the illegal poachers hunt and capture lizards for the collection of hide and for food and medicine. Thus the population of monitor lizards is decreasing day by day. According to the IUCN Red Book of Threatened Amphibia and Reptilia, monitor lizards are endangered animals in Bangladesh.

\section{STUDY AREA}

The study had been operated in four different study sites which are described below:

\section{Dhaka zoo and Botanical Garden areas}

These study sites situated in the Dhaka district between $24^{\circ} \mathrm{W}$ latitude and $90.5^{\circ} \mathrm{E}$ longitudes. It is situated at a height of about $7.62 \mathrm{~m}$ above the sea level. Study areas are entirely plain land and covered by bushes and thickets. Besides, some median and tall tresses along with small water bodies like ponds, ditches and canals are there, too. This included the zoo and botanical garden- the ideal habitat of monitor lizards. Food sources are available there especially near the poultry farms. The main vegetations in this area are as follows; Chatim (Alstonia scholaris), tal (Borassus flabellifera), koroi (Albizzia sp.), krishnachura (Delonix regia), bamboo (Bambosa sp.), coconut (Cocos nucifera), mahagani (Swietenia mahagoni), eucalyptus (Eucalyptus citrioidora), shisso (Dalbergia sissoo), etc.

\section{Kapasia, Gazipur}

This study area is located between $23.92^{\circ}$ and $23.93^{\circ} \mathrm{N}$ latitude and $90.22^{\circ}$ and $90.24^{\circ} \mathrm{E}$ longitude. This study site is in the Gazipur district. Following villages were selected for study; Durgapur, Fulbaria, Polashpur, Taragonj, Khilgaon, Raonat, Dalgaon, etc. Topography is very undulating with many varieties of trees, ponds, ditches, beels, canal, etc. Important plant species are; Chatim (Alstonia scholaris), tal (Borassus flabellifera), koroi (Albizzia sp.), krishnachura (Delonix regia), bamboo (Bambosa sp.), coconut (Cocos nucifera), mahagani (Swietenia mahagoni), eucalyptus (Eucalyptus citrioidora), shisso (Dalbergia sissoo), etc.

\section{Karnai, Thakurgaon district}

This study area is located between $25.79^{\circ}$ and $25.99^{\circ} \mathrm{N}$ latitude and $88.47^{\circ}$ and $88.55^{\circ} \mathrm{E}$ longitude. It is $30 \mathrm{~km}$ far from the district head quarters and situated at the southern part of the district. During the study, this area is surrounded by open country and a few bushes, jungles and wooden trees, bamboo thickets, etc. Most of the areas are plain lands. Habitats of this study area are exceedingly suitable for foraging, breeding, sheltering as well as moving of monitor lizards. Common plant species include Koroi (Albizzia sp.), krishnachura (Delonix regia), nim (Azadirachta indica), bamboo (Bambosa sp.), coconut (Cocos nucifera), mahagani (Swietenia mahagoni), Chatim (Alstonia scholaris), kadam (Anthocephalus kadamba), eucalyptus (Eucalyptus citrioidora), shisso (Dalbergia sissoo), guava (Psidium guyava), dutura (Datura metal), etc.

\section{MATERIALS AND METHODS}

Study was carried out from March 2003 to August 2004, aiming on the study of population, 
feeding ecology and to investigate the factors responsible for conservation of endangered varanid lizards in Bangladesh. Data collection was based on direct observation in the field, interviewing the local people, specimen collection and analysis of gut contents. Manageable numbers of well demarcated sampling sites were selected randomly that covered all micro and macro habitats of the study areas. However, the site selection procedure for sampling was adopted by following ecological factors, for example- horizontal stratification of the areas on the basis of local topography like rivers, canals, beels, basins and terrestrial ecosystem and random selection of transects and plots. A total of 20 plots and 20 transect lines were made for counting lizards from each study site covering all seasons except winter. Study sites were selected in four different ecological habitats as these sites were unique in terms of ecologically sensitive, ideal feeding ground and availability of animal for gut content analysis. Observation was made from 5-10 days in each trip from each field sites.

\section{Plot counting}

By this method lizards were counted randomly in selected small-defined areas called plots $(100 \mathrm{~m}$ $\mathrm{x} 100 \mathrm{~m}$ sizes). Animal falling within each plot were taken into account. For statistical validity, a number of plots covering each macro/microhabitat type were sampled.

\section{Transect line counting}

According to this method imaginary transect lines were set across a sampling site. Observations were made on the animal while walking along the length of the randomly selected lines/paths. Length of the transect lines were always $1 \mathrm{~km}$ and breadth $100 \mathrm{~m}$. The number of individual species falling within each transect was counted and recorded. This method was used for fast moving animals like monitor lizards to estimate the population abundance for each sampling site/habitat type.

\section{Data Collection and analysis}

Observations were made on footprint, trailing, tracks, burrows, nests, animal holes, etc. Besides, local people were interviewed to know the existence and to assess the status of monitor lizards. In addition, photo flashing, complemented with a pair of binocular, was also applied wherever needed. Standard books, field notebooks and field manuals were used for identification of species. However, specimens were caught and brought in the laboratory for proper identification which was done by detail comparison of the components of the skulls and dentition in order to understand variation of species. Photographs were taken as comprehensive collection as possible and to show color patterns on field caught specimens. The external features of varanid taxa had been checked and compared with the departmental preserved specimens. The total number of individuals counted in each selected plot was divided by the area to calculate the occurrence of the monitor lizards per sq $\mathrm{km}$. Gut of monitor lizards was collected for the study of food habit. Sometimes, gut contents were analyzed from picked specimens and those recovered after being killed by the local people. The total of 12 guts of Bengal monitors and 9 guts of yellow monitor were collected in different season and from different research sites. Guts were separated from the body and weigh with foods. Then food items were separated from the gut and weigh again to find the exact consumed food weight. Each food items were identified under microscope and counted them as frequency of occurrence. Data of consumed food item were analyzed to know the preference of food intake. Data of potential threats were evaluated to formulate the management strategy plan. All data were analyzed by SPSS statistical package and GraphPad software. Statistical analysis was set at $5 \%$ level of significance.

\section{RESULTS AND DISCUSSION}

Morphology: An adult Bengal Monitor, Varanus bengalensis was measured up to $1.08 \mathrm{~m}$ in length and up to $9.5 \mathrm{~kg}$ of body mass. It had supraocular 
scales arranged in irregular rows of nearly equal sized scales or single scale sized units are common. The dorsal pattern contains round spots of cream or yellowish on a gray to tan background. On the other hand, Yellow Monitor, Varanus flavescens was yellow colored. The species is an unusual varanid as colored tend to be in tans, browns and black, yellow, red or orange spots but young are slaty gray to black with bright yellow spots. Adult's color is light gray with yellowish head, nape and dorsal spots and catered reddish or orange dorsal spots. Varanus flavescens is much more closely related to $V$. bengalensis rather than other species.

\section{Habits and Habitats}

Bengal monitor, Varanus bengalensis are exceptionally adaptive and inhibited a diverse range of habitats and greatest abundance in agricultural areas (Auffenberg et al. 1991). They are adept runner and mainly feed on the ground and are also climbed well as like squirrels and even take large animals to the trees for feeding (Taylor 1963). In this study Bengal monitor were found using rodent holes along the canals, roads and bank of ponds, embankments and houses, other premises and trees. More often they used paddy field, under bushes, edge of jungles and bamboo thickets as feeding and basking places.

On the other hand, the yellow monitor was found to swim excellently in the water by their strong limbs and tail which was highly adapted for swimming and was always found in and around the aquatic body or seen mainly in the rainy season while swimming over the pond or ditches. It was found that they were also excellent divers and well adapted to stay sometimes under water while predators or enemy came to attack them or ran away and entered into holes or climbed up rapidly on a tree. Both species never used the same home range or ecological niche but change their home range when food was not available and threat was increased.

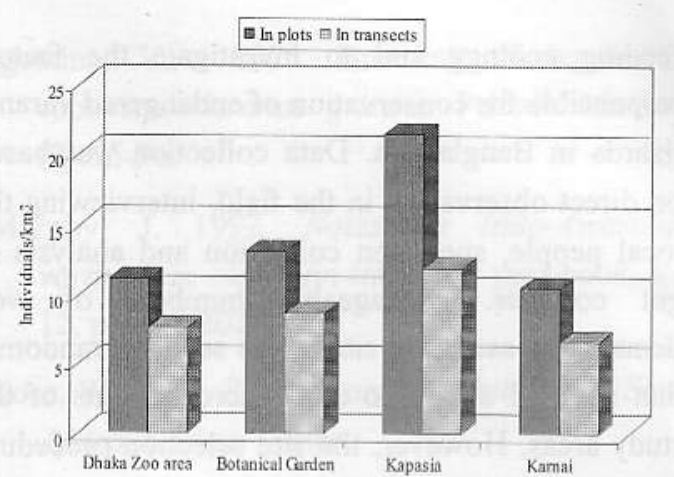

Fig. 1. Population density of Gray land Monitor, Varanus bengalensis.

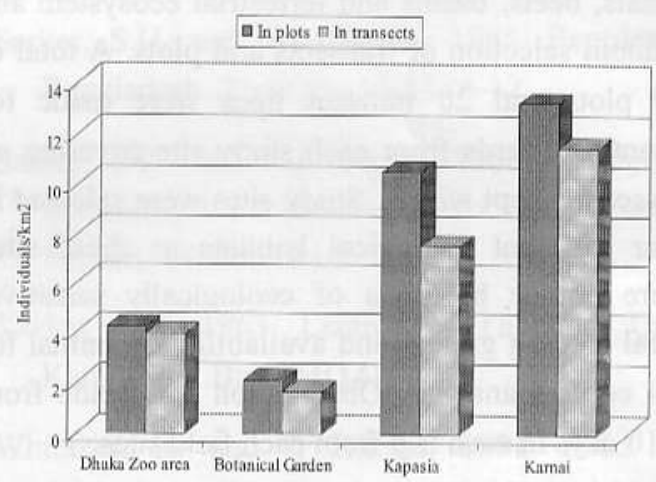

Fig. 2. Population density of Yellow Monitor, Varanus flavescens.

\section{Population of Bengal Monitors}

Bengal Monitor (Varanus bengalensis) was found in all the study areas, though Kapasia study area represented more density of population per kilometer square than the other areas (Fig. 1). Moreover, Bengal monitor in plot censuses showed greater number of individual (average: $92.5 \pm$ 29.38) than that showed in transect lines (average: $57.75 \pm 17.11)$. Average population density in plots was $14.11 \pm 5.66$ individual $/ \mathrm{km}^{2}$, whereas the average density in transect lines was $8.77 \pm 2.96$ individual $/ \mathrm{km}^{2}$. Differences in the number of population of Bengal monitor both in plots and transect lines made in various ecological habitat was highly statistically significant (Chi-square test:

ECOPRINT VOL 14, 2007 
$\chi^{2}=27.99, \mathrm{df}=3, \mathrm{p}<0.001$ and $\chi^{2}=15.22, \mathrm{df}=3$, $\mathrm{p}<0.01$, respectively). The highest population density both in plots (21.42 individual $\left./ \mathrm{km}^{2}\right)$ and in transect lines (11.98 individual $/ \mathrm{km}^{2}$ ) was estimated in Kapasia, Gazipur district (Fig. 1). High density of population in this study area suggested that habitat quality like well breeding ground, food abundance, particularly the more profound habitat cover that provided shelter to escape from predators and enemies. Khan (1982) reported that Varanus bengalensis and $V$. flavescens lived sympatrically, but this study did not find any evidence supporting the claim. In this study both monitors were seen to survive in the different habitat categories like first one was occurred mainly in the terrestrial habitat whereas second one was seen very few time to walk on the land but swam well on the water bodies and tanks.

\section{Population of Yellow Monitors}

Yellow monitor represented the entire studied ecological habitats. The highest densities were estimated to Karnai study area, both in plots $\left(13.26 / \mathrm{km}^{2}\right)$ and transect lines $\left(11.49 / \mathrm{km}^{2}\right)$ (Fig. 2). Average population of 4 studied plots was estimated to be higher ( $51.75 \pm 28.58$ individuals) than that of transect lines (Table 1). Differences of population estimated by plots and transect censuses of this lizard in various ecological habitats were highly statistically significant (Chi-square test: $\chi^{2}$ $=47.36, \mathrm{df}=3, \mathrm{p}<0.001$ and $\chi^{2}=57.0, \mathrm{df}=3$, $\mathrm{p}<0.001$, respectively). It seemed that the highest population in Karnai was due to the availability of aquatic bodies surrounded by bamboo thickets, crop lands as well as bushes near the house holds. Large population of monitors had indicated that the ecological conditions like shelter, less predator risk and food abundance, etc were much better than that of other habitats.

Table 1. Population density of monitor lizards in different foraging habitat.

\begin{tabular}{|c|c|c|c|c|c|c|c|c|}
\hline \multirow[t]{2}{*}{ Study area } & \multirow{2}{*}{$\begin{array}{c}\text { Village/wards/ } \\
\text { locations }\end{array}$} & \multirow{2}{*}{$\begin{array}{l}\text { Census } \\
\text { Method }\end{array}$} & \multirow[t]{2}{*}{ Name of lizards } & \multicolumn{3}{|c|}{ Number of monitor lizards } & \multirow[t]{2}{*}{ Total } & \multirow{2}{*}{$\begin{array}{c}\text { Density } \\
/ \mathrm{km}^{2}\end{array}$} \\
\hline & & & & Juvenile & Young & Adult & & \\
\hline \multirow[t]{4}{*}{ Dhaka Zoo area } & \multirow{4}{*}{$\begin{array}{l}\text { Outside of zoo } \\
\text { areas }\end{array}$} & \multirow[t]{2}{*}{ Plot } & Bengal monitor & 15 & 22 & 31 & 68 & 11.23 \\
\hline & & & Yellow monitor & 12 & 16 & 21 & 49 & 4.23 \\
\hline & & \multirow[t]{2}{*}{ Transect } & Bengal monitor & 11 & 17 & 23 & 51 & 7.66 \\
\hline & & & Yellow monitor & 05 & 03 & 07 & 15 & 3.93 \\
\hline \multirow[t]{4}{*}{ Botanical Garden } & \multirow{4}{*}{$\begin{array}{l}\text { in and outside of } \\
\text { whole botanical } \\
\text { garden }\end{array}$} & \multirow[t]{2}{*}{ Plot } & Bengal monitor & 25 & 27 & 43 & 95 & 13.22 \\
\hline & & & Yellow monitor & 4 & 5 & 6 & 15 & 2.09 \\
\hline & & \multirow[t]{2}{*}{ Transect } & Bengal monitor & 15 & 12 & 25 & 52 & 8.76 \\
\hline & & & Yellow monitor & 00 & 02 & 04 & 06 & 1.67 \\
\hline \multirow[t]{4}{*}{ Kapasia, Gazipur } & \multirow{4}{*}{$\begin{array}{l}\text { Durgapur, } \\
\text { Fulbaria, } \\
\text { Polashpur, } \\
\text { Tragonj, Khilgaon, } \\
\text { Raonat Dalgaon } \\
\end{array}$} & \multirow[t]{2}{*}{ Plot } & Bengal monitor & 33 & 42 & 58 & 133 & 21.42 \\
\hline & & & Yellow monitor & 17 & 19 & 23 & 59 & 10.58 \\
\hline & & \multirow{2}{*}{ Transect } & Bengal monitor & 19 & 28 & 36 & 83 & 11.98 \\
\hline & & & Yellow monitor & 17 & 13 & 27 & 57 & 7.56 \\
\hline \multirow[t]{4}{*}{ Karnai } & \multirow{4}{*}{$\begin{array}{l}\text { Mazapara, } \\
\text { Sarkerpara, } \\
\text { Langolpara, } \\
\text { poschimpara and } \\
\text { morolpara }\end{array}$} & \multirow[t]{2}{*}{ Plot } & Bengal monitor & 17 & 21 & 36 & 74 & 10.56 \\
\hline & & & Yellow monitor & 21 & 25 & 38 & 84 & 13.26 \\
\hline & & \multirow[t]{2}{*}{ Transect } & Bengal monitor & 9 & 14 & 22 & 45 & 6.67 \\
\hline & & & Yellow monitor & 10 & 11 & 24 & 45 & 11.49 \\
\hline
\end{tabular}


Inter-species comparison of population

The overall average population of Bengal monitors was higher in both plots and transects lines $(92.5 \pm 29.38, \mathrm{~N}=4$ and $57.75 \pm 17.11, \mathrm{~N}=4$, respectively) than the population of yellow monitors (Table 1). Occurrence of Bengal monitor in each plot $(4.63 \pm 2.54$ individual $/$ plot $)$ and in each transect $(2.89 \pm 1.82$ individual/transect $)$ was significantly higher (Paired t test: $T=5.57, N=80$, $\mathrm{p}<0.001$ and $\mathrm{T}=5.31, \mathrm{~N}=80, \mathrm{p}<0.001$ respectively) than that of yellow monitor $(2.59 \pm 1.89$ individual/plot and $1.54 \pm 1.54$ individual/ transect).

Table 2. Food items found in the gut of Bengal Monitor, Varanus bengalensis.

\begin{tabular}{|c|c|c|c|c|}
\hline \multirow[t]{2}{*}{ Name of food items } & \multirow[t]{2}{*}{ Family/ order/class/phylum } & \multirow{2}{*}{$\begin{array}{c}\text { Frequency of } \\
\text { occurrence }\end{array}$} & \multicolumn{2}{|c|}{ Item \% } \\
\hline & & & ${ }^{*} \mathrm{~A}$ & B* \\
\hline Metaphaire posthuma & Megascolicidae, Annelida & 105 & 875.00 & 28.30 \\
\hline Hirudinaria sp. & Gnathobdellia & 2 & 16.67 & 0.54 \\
\hline Pila globossa & Pilidae, Mollusca & 5 & 41.67 & 1.35 \\
\hline Bellamya spp. & Mollusca & 7 & 58.33 & 1.89 \\
\hline Lamellidens sp. & Unionidae, Mollusca & 2 & 16.67 & 0.54 \\
\hline Julus spp. & Diplopoda, Arthropoda & 4 & 33.33 & 1.08 \\
\hline Portunus spp. & Decapoda & 40 & 333.33 & 10.78 \\
\hline Macrobrachium spp. & Decapoda & 20 & 166.67 & 5.39 \\
\hline Gryllus sp. & Orthoptera & 12 & 100.00 & 3.23 \\
\hline Gryllotalpa sp. & Orthoptera & 6 & 50.00 & 1.62 \\
\hline Belostoma sp. & Hemiptera & 4 & 33.33 & 1.08 \\
\hline Pelocoris sp. & Hemiptera & 2 & 16.67 & 0.54 \\
\hline Trox sp. & Coleoptera & 10 & 83.33 & 2.70 \\
\hline Calosoma spp. & Coleoptera & 4 & 33.33 & 1.08 \\
\hline Phylophaga sp. & Coleoptera & 2 & 16.67 & 0.54 \\
\hline Geotropes sp. & Coleoptera & 20 & 166.67 & 5.39 \\
\hline Platycentropus sp. & Trichoptera & 8 & 66.67 & 2.16 \\
\hline Nepytia canosaria & Lepidoptera & 2 & 16.67 & 0.54 \\
\hline Musca domestica & Diplopoda & 2 & 16.67 & 0.54 \\
\hline Scolopendra sp. & Chilopoda & 12 & 100.00 & 3.23 \\
\hline Bufo melanostictus & Amphibia & 6 & 50.00 & 1.62 \\
\hline Bones of Toad & Amphibia & 2 & 16.67 & 0.54 \\
\hline Kachuga tecta & Reptilia & 2 & 16.67 & 0.54 \\
\hline Bones of Turtle & Reptilia & 1 & 8.33 & 0.27 \\
\hline Bones of fishes & Osteichthyes & 7 & 58.33 & 1.89 \\
\hline Bird feathers & Aves & 6 & 50.00 & 1.62 \\
\hline Egg shell of birds & Aves & 7 & 58.33 & 1.89 \\
\hline Rats and mice bones & Mammals & 20 & 166.67 & 5.39 \\
\hline $\begin{array}{l}\text { (Grasses, roots, seeds, } \\
\text { paddy, leaf) }\end{array}$ & Plant matters & 47 & 391.67 & 12.67 \\
\hline $\begin{array}{l}\text { (Cracking bricks, papers, } \\
\text { etc.) }\end{array}$ & Non-living matters & 4 & 33.33 & 1.08 \\
\hline
\end{tabular}




\section{Food and feeding habits of Bengal Monitor}

Bengal monitors are carnivore animals, as they consumed animal food, especially predates on insects and small mammals like rats and mice from the agricultural fields, farmlands, gardens, home yards, etc. Average weight of gut of adult monitor was $2005 \pm 709.47 \mathrm{~g}(\mathrm{~N}=12)$. Average weight of food consumption was $92 \pm 19.5 \mathrm{~g}(\mathrm{~N}=12)$. A total of 371 food items were identified from the 12 guts analyzed (Table 2). Among the total food items, animal food was $320(86.25 \%)$ and plant food items was $47(12.67 \%)$ (Table 2). Arthropods (39.89\%) was most preferred food items followed by annelids $(28.84 \%)$ and vertebrate food items including fishes to some smalls mammals like rats and mice (13.75\%). Among the arthropods, Decapodans $(16.17 \%)$ was found to be the most preferred food items to this monitor followed by coleopterans $(9.7 \%)$ and orthopterans $(4.85 \%)$ food items (Table 2 and Fig. 3).

Among the vertebrate animals the highest consumption was rats and mice (5.39\%) (Table 2). It indicated that other than insect pest control, monitors also played an important role in controlling rate and mice pest. The overall proportion of different food consumption was significantly different (Chi-square test: $\chi^{2}=38.5$, $\mathrm{df}=4, \mathrm{p}<0.001$ ) (Fig. 3). The present findings was supported by Auffenberg (1983c, 1988) that juveniles feed largely on snails and crabs while adult feed on crabs, spiders, orthopterans, beetles, ants, other small invertebrates, birds, etc.

\section{Food and feeding habits of Yellow Monitor}

The average weight of full gut was $1787 \pm$ $655.57 \mathrm{~g}(\mathrm{~N}=9)$. The average weight of food in the gut was $77 \pm 13.6 \mathrm{~g}(\mathrm{~N}=9)$. A total of 301 food items were identified from 9 guts analyzed. Among the total food items, $247(82.06 \%)$ was animal foods, $41(13.62 \%)$ plant foods and $13(4.32 \%)$ non-living items (Table 3 and Fig. 4). Vertebrate food items were most preferred (54.82\%) among the animal food followed by arthropods (17.61\%) food items (Table 3 and Fig. 4). Among the vertebrate food items, the highest proportion was fishes $(27.24 \%)$ followed by amphibians (11.63\%) and rats and mice (7.31\%) (Table 3). Among the arthropod food items, 22 (7.31\%) was insects, 19 (6.31\%) prawns and $12(3.99 \%)$ crabs (Table 3). It was observed that insect food item was most preferred among the arthropods. The overall proportion of food items by this species was significantly different (Chi-square test: $\chi^{2}=85.9$, $\mathrm{df}=4, \mathrm{p}<0.001$ ) (Fig. 4).

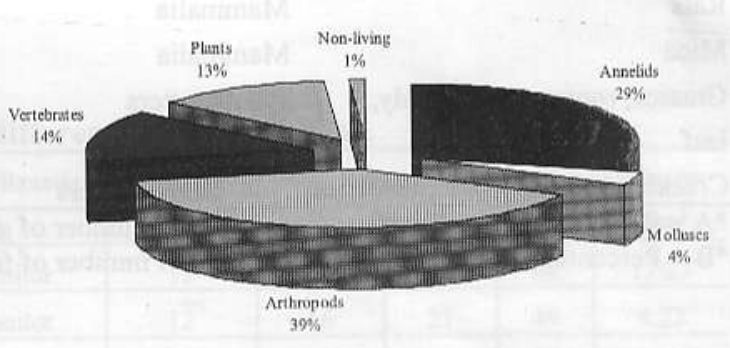

Fig. 3. Food consumptions by Gray Land Monitor, Varanus bengalensis.

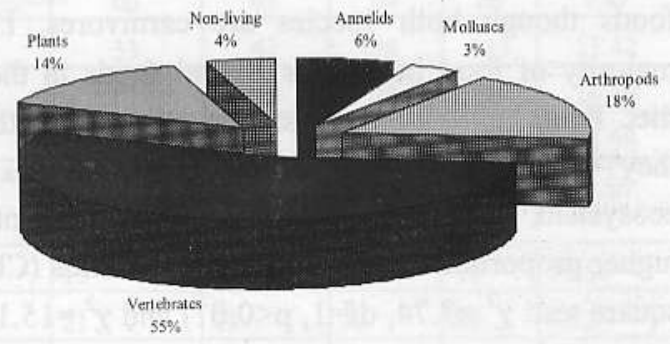

Fig. 4. Food consumptions by Yellow Monitor, Varanus flavescens. 
Table 3. Food items found in the gut of Yellow Monitor, Varanus flavescens.

\begin{tabular}{|c|c|c|c|c|}
\hline \multirow[t]{2}{*}{ Name of food items } & \multirow[t]{2}{*}{ Family/ order/class/phylum } & \multirow{2}{*}{$\begin{array}{c}\text { Frequency of } \\
\text { occurrence }\end{array}$} & \multicolumn{2}{|c|}{ Item percentage } \\
\hline & & & ${ }^{*} \mathrm{~A}$ & $\mathrm{~B}^{*}$ \\
\hline Metaphaire sp. & Megascolicidae, Annelida & 19 & 211.11 & 6.31 \\
\hline Bellamya spp. & Mollusca (fresh water snail) & 10 & 111.11 & 3.32 \\
\hline Crab & Arthropoda & 12 & 133.33 & 3.99 \\
\hline Prawn & Arthropoda & 19 & 211.11 & 6.31 \\
\hline Belostoma sp. & Hemiptera & 15 & 166.67 & 4.98 \\
\hline Dragon fly & Odonata & 7 & 77.77 & 2.33 \\
\hline Fish (whole body) & Osteichthyes & 9 & 100.00 & 2.99 \\
\hline Fish scale & Osteichthyes & 31 & 344.44 & 10.30 \\
\hline Fish bones & Osteichthyes & 42 & 466.67 & 13.95 \\
\hline Toad & Amphibia & 3 & 33.33 & 1.00 \\
\hline Bones of Toad & Amphibia & 9 & 100.00 & 2.99 \\
\hline Tadpoles & Amphibia & 23 & 255.56 & 7.64 \\
\hline Turtles & Reptilia & 2 & 22.22 & 0.67 \\
\hline Bones of Turtle & Reptilia & 1 & 8.33 & 0.27 \\
\hline Bones of snakes & Reptilia & 11 & 122.22 & 3.65 \\
\hline Birds feather & Aves & 9 & 100.00 & 2.99 \\
\hline Egg shell of birds & Aves & 4 & 44.44 & 1.33 \\
\hline Rats & Mammalia & 17 & 188.89 & 5.65 \\
\hline Mice & Mammalia & 5 & 55.56 & 1.66 \\
\hline $\begin{array}{l}\text { Grasses, roots, seeds, paddy, } \\
\text { leaf }\end{array}$ & Plant matters & 41 & 455.56 & 13.62 \\
\hline Cracking bricks, papers, etc. & Non-living matters & 13 & 144.44 & 4.32 \\
\hline
\end{tabular}

\section{Inter-species feeding comparison}

The Bengal monitor preferred arthropod foods, particularly insect food items while the yellow monitor consumed high proportion of vertebrate foods though both species are carnivores, i.e., majority of food items was animal foods in their diet. Food habits of these monitors suggested that they were the integral part of food chain and ecosystem. Bengal monitor consumed significantly higher proportion of arthropods and annelids (Chisquare test: $\left.\chi^{2}=7.74, \mathrm{df}=1, \mathrm{p}<0.01\right)$ and $\chi^{2}=15.11$, $\mathrm{df}=1, \mathrm{p}<0.001$, respectively) than that of yellow monitor (Fig. $3 \& 4$ ). On the other hand yellow monitor consumed significantly higher proportion of vertebrate food items (Chi-square test: $\chi^{2}$
$=24.36, \mathrm{df}=1, \mathrm{p}<0.001)$ than that of Bengal monitor (Fig. 3 \& 4). Differences in consumption of other food items by these monitor lizards were not statistically significant.

\section{CONSERVATION PROBLEMS AND RECOMMENDATIONS}

Monitor lizards bred from March to June and peak period was in May. They make their nest in the holes near the base of old trees or safe side of the bushy grounds. It was found that they laid 7-20 eggs in a nest in one study site. Breeding was disturbed as they lost their habitat like bushy areas near the water bodies and basking place as well as sheltering from predators. Moreover, no one has 
been responsible for the protection of that important component of our natural environment from the illegal hunters and poachers in the country. If appropriate protection measures have not been taken on this group of lizard they will be extinct in near future. As a result monitor lizards now-a-day had been recognized nationally endangered animal (IUCN Red Data Book, 2000). However, their contribution to the eco-balance by destroying harmful animals as well as saving our farmlands is considerably high. As such, we need to pay proper heed to the conservation of these valuable species. According to this study, two different species of lizards- the Bengal and Yellow monitor inhabited in two distinct ecosystems around with the particular environment and natural food sources they prefer. Therefore, special care must be taken by involving the local communities, women in particular to make sure that these ecological balances are nurtured and maintained in order to allow the lizards to breed and grow safely. Attention should be paid in conserving the ideal habitats and its components like vegetations, waters, etc that the lizards are used to live with them. The particular food sources must not be destroyed by using chemical fertilizers and pesticides so that the lizards may find proper foods to continue the food web. Once the ideal conservation of lizards is attained, the number of lizards would increase significantly which would in turn provide excess numbers for profitable leather industry and business. Sustainable use of natural resources like flora and fauna by all sectors of society, particularly in the community level requires for the conservation of monitors. Since the existence of monitors has social and environmental significance, the government should formulate appropriate policy like applying wildlife protection laws properly by local enforcement authorities, make social awareness to address the significance of monitor lizards in our ecosystem and economy, and hence, the need for conservation of them. The

ECOPRINT VOL 14, 2007 local community people develop realization that the monitor lizards is a very important animal group within the ecosystem as they predates on insect pest, snakes, rats and mice and play a vital role in controlling population of harmful animals.

\section{ACKNOWLEDGEMENT}

MFJ wishes to express his sincere gratitude to late Professor Mahmud-ul Ameen, Department of Zoology, University of Dhaka for his valuable suggestions during data collection. The author is grateful to the Ministry of Science and Information \& Communication Technology, Government of the People's Republic of Bangladesh, Bangladesh Secretariat, Dhaka, for the financial assistance.

\section{REFERENCES}

Ahsan, F. 1996. Herpeto-fauna of Bangladesh: present status, distribution and conservation. An international conference on the biology and conservation of the South Asian Amphibians \& Reptiles, 1-5, August, Sri Lanka.

Akond, A.W., F. Ahsan and M. Rahman. 1982. Monitor lizards of Bangladesh. Proc. $2^{\text {nd }}$ Nat. Conf. Bangladesh. 540-545 pp.

Anon. 2000. Red book of Threatened Amphibia and Reptilia of Bangladesh. IUCN - World Conservation Union, $\mathrm{xi}+95 \mathrm{pp}$.

Auffenberg, W. 1981. Combat behavior of Varanus bengalensis (Sauria : Varanidae) $J$. Bombay Nat. Hist. Soc. 78(1):54-72.

Auffenberg, W. 1983. Notes on feeding behavior of Varanus bengalensis. J. Bombay Nat. Hist. Soc. 80(2):286-302.

Auffenberg, W. 1988. Gray's Monitor Lizard. University Presses of Florida, Gainesville,xi+419 p.

Auffenberg, W., H. Rahman, F. Iffat and Z. Perveen. 1989. A study of Varanus flavescens (Sauria : Varanidae). J. Bombay Nat. Hist. Soc. 86(3):286-307. 
Auffenberg, W., Q. N. Arain and N. Kurshid. 1991. Preferred habitat, home range and movement patterns of Varanus bengalensis in Southern Pakistan. Mertensiella. 2:7-28.

Cowles, R.B. 1930. The life history of Varanus. niloticus as observed in Natal, S. Africa, $J$. Entomology and Zoology (Pomona, Calif.) 22(1):1-32.

Daniel, J.C. 1992. The book of Indian Reptiles. Bombay Nat. Hist. Soc.,Oxford University Press, Bombay, India. $\mathrm{x}+141 \mathrm{pp}$.

Deraniyagala, P.E.P. 1939. Tetrapod Reptiles of Ceylon. Vol.1 Dulau and Co., London.

Deraniyagala, P.E.P. 1953. Tetrapod Reptiles of Ceylon. Vol.2, Govt. Press.

Hossain, M.L. and S.U. Sarker. 1996. Ecology of the Grey Land Monitor, Varanus Bengalensis L. of the Hatiya Island, Noakhali, Bangladesh. Bangladesh J. Zool. 24(1):21-24.

Hossain, M.L., S.U. Sarker and N. J. Sarker. 1995. Food habits and feeding behaviour of Grey Land Monitor (Varanus bengalensis) at Hatiya Island, Noakhali, Bangladesh. Dhaka Univ. J. Biol. Sci. 4(2):173-181.

Hvass, H. 1964. Reptiles and Amphibians of the World. Methuen and Co. Ltd. London, 125 pp.
Igolkina, V.A. 1975. Breeding of reptiles in captivity: Varanus grisens. Priroda Moskov. (9):95-96.

Murphy, J. 1992. Notes on Indo-Australian varanids in captivity; Int'1. 200 year book, Vol 12, pp.199-202.

Rose, W. 1967. Reptiles and Amphibians of South Africa. Nasken Miller.

Sarker, S.U. 1991. Endangered and Threatened wildlife of the coastal zone of Bangladesh. $J$. NOAMI. 3(2):29-37.

Sarker, S.U. and N.J. Sarker. 1985. Reptiles of Bangladesh. Tiger paper. 12: 6-12.

Sarker, S.U. and N.J. Sarker. 1988. Wildlife of Bangladesh - a systematic list. Rico Printers, Nilkhet, Dhaka, 59 pp.

Taylor, E.H. 1963. Lizards of Thailand. Univ. Kansas Sci. Bull. 44(14).

Whitaker, R. and J. Hikida. 1981. Food and Agriculture Organization of the United Nation Action program for the prevention of food Losses Report of project Formulation in Mission to Bangladesh. Proceeding, June 20July 22. 